\title{
PENGARUH KOSENTRASI EDIBLE COATING SARANG LEBAH TERHADAP SUSUT BOBOT, TEKSTUR, DAN TPT JERUK RGL SELAMA PENYIMPANAN
}

\section{THE EFFECT OF CONCENTRATION OF COATING EDIBLE HONEY NUTS ON THE BOTTOM, TEXTURE, AND RGL TPT AS THE STORAGE}

\author{
Taufik Hidayat ${ }^{1}$, Lina Ivanti' ${ }^{1}$, dan Wilda Mikasari ${ }^{1)}$ \\ ${ }^{1)}$ Balai Pengkajian Teknologi Pertanian (BPTP) Bengkulu \\ e-mail : taufikhidayatveydo@gmail.com
}

\begin{abstract}
ABSTRAK
Jeruk merupakan komoditas hortikultura yang sangat potensial untuk dikembangkan di Indonesia karena paling banyak dikonsumsi masyarakat dan menempati urutan pertama untuk pengeluaran belanja buah rata-rata masyarakat Indonesia, baik di desa maupun di kota. Jeruk Rimau Gerga Lebong (RGL) atau yang biasa dikenal dengan sebutan jeruk Gerga merupakan salah satu komoditas hortikultura unggulan daerah di provinsi Bengkulu. Penanganan pascapenen jeruk RGL perlu dilakukan untuk mempertahankan kualitas jeruk RGL agar sampai ditangan konsumen dalam keadaan yang baik. Penelitian ini bertujuan untuk mengetahui pengaruh kosentrasi edible coating dari sarang lebah terhadap penurunan susut bobot, tekstur dan TPT buah jeruk RGL selama penyimpanan. Rancangan penelitian ini menggunakan metode Rancangan Acak Lengkap Faktorial yang terdiri dari dua faktor perlakuan yaitu faktor kosentrasi edible coating dari sarang lebah L1 $=6 \%, \mathrm{~L} 2=9 \%$ dan L3 $=12 \%$ serta $\mathrm{L} 0=0 \%$ sebagai kontrol dan faktor kedua umur simpan $\mathrm{T} 1=0$ hari, $\mathrm{T} 2=3$ hari, $\mathrm{T} 3=6$ hari, $\mathrm{T} 4=9$ hari, $\mathrm{T} 5=12$ hari, $\mathrm{T} 6=15$ hari, $\mathrm{T} 7=18$ hari, $\mathrm{T} 8=21$ hari, $\mathrm{T} 9=24$ hari, $\mathrm{T} 10=27$ hari dan $\mathrm{T} 11=30$ hari dengan jumlah sampel yang diukur sebanyak 30 butir buah jeruk sebagai ulangan. Variabel yang diamati antara lain adalah susut bobot, tekstur kekerasan kulit jeruk (penetrometer) dan total padatan terlarut/TPT (refraktometer). Data yang diperoleh kemudian dianalisis statistik menggunakan sidik ragam. Apabila hasil $\mathrm{F}$ hitung > atau sama dengan F tabel maka dilakukan uji beda DMRT pada taraf 5\%. Hasil penelitian menunjukkan bahwa penggunaan edible coating sebagai lapisan pelindung di bagian luar kulit jeruk diketahui mampu menahan kerusakan dan mempertahankan kualitas jeruk RGL. Perbedaan kadar edible coating yang diberikan untuk melapisi permukaan kulit luar jeruk RGL menekan laju respirasi sehingga mengurangi susut bobot yang terjadi. Kadar edible coating $12 \%$ diketahui yang paling baik dalam melindungi jeruk RGL selama penyimpanan terlihat dari susut bobot dan tekstur jeruk RGL, sementara peedible coatingan jeruk RGL tidak memberi pengaruh terhadap total padatan terlarut (TPT) jeruk RGL tetapi dipengaruhi oleh lama penyimpanan.
\end{abstract}

Kata Kunci: kualitas jeruk RGL, peedible coatingan, umur simpan, susut bobot

\section{ABSTRACT}

Oranges are horticultural commodities that are very potential to be developed in Indonesia because they are mostly consumed by the public and rank first for the average fruit expenditure in Indonesia, both in the village and in the city. Rimau Gerga Lebong Orange 
(RGL) or commonly known as Gerga orange is one of the leading regional horticultural commodities in Bengkulu province. Post-harvest handling of RGL oranges needs to be done to maintain the quality of RGL oranges so that they reach the consumers in good condition. This study aims to determine the effect of edible coating concentration from honeycomb on decreasing weight loss, texture and TPT of RGL citrus fruits during storage. The design of this study used the Factorial Completely Randomized Design method which consisted of two treatment factors, namely beeswax concentration factor $L 1=6 \%, L 2=9 \%$ and $L 3=12 \%$ and $L O=0 \%$ as control and the second factor shelf life $T 1=0$ days, T2 $=3$ days, T3 = 6 days, $T 4=9$ days, $T 5=12$ days, $T 6=15$ days, $T 7=18$ days, $T 8=21$ days, $T 9=24$ days, $T 10=24$ days, $T 10=27$ days and $T 11=30$ days with the number of samples measured as many as 30 citrus fruits as a test. Variables observed were weight loss, the texture of orange skin hardness (penetrometer) and total dissolved solids (TPT) (refractometer). The data obtained were then analyzed statistically using variance. If the result of $F$ count $>$ or equal to $F$ table, a different DMRT test is carried out at the level of 5\%. The results showed that the use of wax as a protective layer on the outside of the orange peel is known to be able to withstand damage and maintain the quality of RGL oranges. The difference in the level of wax given to coat the surface of the outer skin of oranges RGL suppresses the rate of respiration thereby reducing the weight loss that occurs. The $12 \%$ wax content is known to be the best in protecting RGL oranges during storage seen from the weight loss and texture of $R G L$ oranges, while RGL orange wrapping does not affect the total soluble solids (TPT) of RGL oranges but is affected by storage time.

Keywords: RGL orange quality, winding, shelf life, weight loss

\section{PENDAHULUAN}

Salah satu komoditas hortikultura yang sangat potensial dikembangkan di Indonesia adalah jeruk (Soelarso, 1996), mengingat komoditas jeruk menempati urutan ketiga sebagai buah yang paling banyak dikonsumsi masyarakat Indonesia, dengan tingkat konsumsi 3,28/kapita/tahun pada 2015 dan naik menjadi 3,60/kg/kapita/tahun pada 2016 . (Kementerian Pertanian RI, 2018). Berdasarkan National Social and Economic Survey household consumption and expenditure supplement, jeruk menempati urutan pertama untuk belanja konsumsi buah rata-rata masyarakat Indonesia (dalam rupiah), baik di desa maupun di kota. Komoditas jeruk mempunyai peran yang penting untuk memenuhi kebutuhan konsumsi buah masyarakat Indonesia, membuka kesempatan kerja serta meningkatkan pendapatan masyarakat. Jeruk yang berkembang di Indonesia digolongkan menurut jenisnya, yaitu jeruk siam, jeruk keprok dan jeruk besar (pamelo).

Produksi jeruk di Provinsi Bengkulu pada tahun 2017 sebesar 9.042,6 ton/ha (BPS, 2017). Jeruk Rimau Gerga Lebong (RGL) atau yang biasa dikenal dengan sebutan jeruk gerga merupakan salah satu komoditas hortikultura unggulan daerah di Provinsi Bengkulu. Komoditas tanaman jeruk RGL 
ini berkembang pesat di Kabupaten Lebong, bahkan saat ini sudah mulai dikembangkan juga di Kabupaten Rejang Lebong dan Kabupaten Kepahiang. Jeruk RGL mempunyai keungguan kompetitif dari jeruk lainnya, yaitu buahnya yang berwarna kuning-orange, berbuah sepanjang tahun, ukuran buah relatif besar dengan bobot berkisar antara 200-350 gram, dan memiliki kadar sari buah yang tinggi (Suwantoro, 2010). Karena keunggulannya tersebut, mulai tahun 2011 telah ditetapkan jeruk keprok ini sebagai prioritas nasional untuk dikembangkan dari luas lahan sekitar 6 hektar pada tahun 2010, menjadi kawasan agribisnis hortikultura di bekas lahan tidur seluas 6000 hektar untuk lima tahun mendatang (Ditjen Hortikultura, 2010).

Perlu diketahui bahwa buah jeruk termasuk buah yang mudah mengalami kerusakan dan termasuk buah nonklimaterik. Buah nonklimaterik setelah dipanen tetap melakukan aktivitas metabolisme yang meliputi respirasi dan transpirasi. Aktivitas ini mengakibatkan kehilangan subtrat dan air pada buah sehingga bobot buah menurun. Menurut Kader (2006), kehilangan air tidak saja berpengaruh langsung terhadap kehilangan kualitatif, tetapi juga menyebabkan kerusakan tekstur, kandungan gizi dan kerusakan lainnya (penegrutan). Aktivitas respirasi juga dapat menurunkan kandungan vitamin $\mathrm{C}$ pada buah karena asam askorbat sangat peka terhadap oksidasi. Selain itu, aktivitas respirasi juga mengakibatkan padatan terlarut pada buah semakin besar akibat akumulasi gula hasil metabolisme pati (Pantastico, 1986)

Penanganan pascapanen jeruk RGL perlu dilakukan untuk mempertahankan kualitas jeruk RGL agar sampai ditangan konsumen tetap dalam keadaan yang baik. Salah satu cara untuk mempertahankan mutu dan kesegarannya adalah dengan melapisi buah dengan edible coating. Pelapisan edible coating pada permukaan kulit jeruk dapat mencegah terjadinya penguapan air sehingga menghambat laju respirasi, dan mengkilapkan kulit buah. Pelapisan edible coating dengan kepekatan dan ketebalan yang sesuai dapat menghindarkan keadaan aerobik pada buah dan memberikan perlindungan yang diperlukan terhadap luka dan goresan pada permukaan buah (Pantastico, 1986).

Beberapa syarat yang diperlukan untuk edible coating sebagai bahan pelapis antara lain : tidak mempengaruhi bau dan rasa buah yang dilapisi, mudah kering, tidak mudah pecah, mengkilap dan licin, tidak menghasilkan permukaan yang tebal, murah harganya, dan tidak beracun (Furness, 1997). Edible coating yang memenuhi syarat tersebut adalah lilin dari 
sarang lebah (beeswax). Lilin dari sarang lebah merupakan salah satu edible coating yang sifat kimianya stabil dengan titik lebur berkisar $61-69^{0} \mathrm{C}$, berat jenis pada $20^{\circ} \mathrm{C}$ sekitar 0,96 , tidak larut dalam air dan sedikit larut dalam alkohol dingin. Lilin sarang lebah mengandung senyawa organik hidrokarbon jenuh, ester dan alkohol (Brown, 1981). Pelepasan tutup madu menghasilkan 0,45-0,91 kg lilin lebah per 43,5 $\mathrm{kg}$ madu terekstraksi (Sihombing, 1997). Berdasarkan eksperimen Whhitcomb pada tahun 1946, setiap 6,66 sampai 8,8 pound madu sihasilkan 1 pound lilin (Coggshall, 1984) sementara Les Crowder, 2012 mendapatkan angka 24-30 pounds lilin lebah per 1 pounds madu. Lilin lebah yang berwarna kuning kualitasnya lebih baik karena lebih mudah dan cepat diputihkan (Ismiarni, 1996).

Pelapisan edible coating pada buah bertujuan membuat kulit buah tampak bersinar, mempertahan kan kualitas buah serta memperpanjang umur simpan dengan menekan laju respirasi dan traspirasi yang masih terjadi setelah panen. Suhu penyimpanan jeruk biasanya disesuaikan dengan karakteristik buah jeruk yang akan disimpan. Sebagai contoh, grape fruit dan lemon perlu disimpan pada suhu $12^{\circ} \mathrm{C}$, jeruk naval dan valencia antara $7-10^{\circ} \mathrm{C}$, dan mandarin pada suhu $5^{\circ} \mathrm{C}$. Diperkirakan pada suhu tersebut, grape fruit, valencia, dan lemon dapat disimpan selama 3 (tiga) bulan (Akadongan H. 1999). Untuk itu, perlu dilakukan penelitian penanganan pascapanen jeruk RGL berupa peedible coatingan. Penelitian ini bertujuan untuk mengetahui pengaruh kosentrasi edible coating dari sarang lebah terhadap penurunan kualitas dan waktu daya simpan.

\section{BAHAN DAN METODE}

Penelitian dilakukan di laboratorium pascapanen BPTP Balitbangtan Bengkulu dari bulan Mei 2018 sampai dengan bulan Agustus 2018. Bahan baku yang digunakan dalam penelitian ini adalah buah jeruk RGL yang diambil langsung dari kecamatan Rimbo Pengadang Kabupaten Lebong yang merupakan tempat asal jeruk RGL ini dibudidayakan. Jeruk yang baru dipetik, dikemas dalam kotak kardus dan langsung dibawa ke laboratorium pascapanen BPTP Balitbangtan Bengkulu. Lamanya jeruk RGL setelah dipetik dan didistribusikan sampai dilakukan proses peedible coatingan memakan waktu sekitar 4 hari. Sehingga, jeruk yang digunakan merupakan jeruk dengan umur 4 hari setelah dipetik. 


\section{Bahan dan Alat}

Bahan yang digunakan dalam penelitian ini antara lain adalah jeruk RGL yang telah dibersihkan, edible coating dari sarang lebah, Emulsifier Tritanolamim (TEA), asam oleat dan aquades. Sementara alat yang digunakan antara lain adalah wajan, pisau, timbangan analitik, fruit penetrometer, refraktometer, thermohigrometer, dll.

\section{Tahapan Pelaksanaan}

Penelitian diawali dengan proses pembuatan edible coating untuk melapisi lapisan luar kulit jeruk RGL. Kosentrasi edible coating yang digunakan yaitu $6 \%$, 9\% dan $12 \%$ dibuat dengan memanaskan terlebih dahulu edible coating dari sarang lebah hingga mencair. Bersamaan dengan itu, panaskan aquades, lalu campurkan TEA sebanyak $20 \mathrm{ml}$ dan asam oleat sebanyak $10 \mathrm{ml}$ ke dalam aquades panas tersebut. Setelah itu campurkan campuran tersebut ke dalam edible coating dari sarang lebah cair dan diaduk sampai merata. Dinginkan campuran edible coating dari sarang lebah tersebut hingga bersuhu ruang. Edible coating dari sarang lebah siap digunakan untuk melapisi lapisan luar kulit jeruk RGL.

Perlakuan emulsi edible coating dari sarang lebah dengan tiga konsentrasi edible coating yang berbeda-beda yang digunakan dalam penyimpanan jeruk RGL ini dapat dilihat pada tabel 1.

Buah jeruk RGL yang akan dilapisi edible coating dari sarang lebah dibersihkan dengan cara pencucian menggunakan klorin untuk menghilangkan kontaminasi residu fungisida, spora jamur, dan tanah/kotoran kemudian dilakukan pengelapan dengan kain basah. Kemudian buah jeruk RGL dicelupkan kedalam emulsi edible coating dari sarang lebah sesuai dengan kosentrasi perlakuan selama 30 detik, lalu ditiris dan dikering-anginkan. Selanjutnya dilakukan penyimpanan buah jeruk RGL selama 30 hari pada suhu ruang $24-25{ }^{0} \mathrm{C}$ dengan kelembaban relatif $85-95 \%$.

Tabel 1. Pelakuan Kosentrasi Emulsi Edible Coating dari Sarang Lebah untuk Melapisi Jeruk RGL

\begin{tabular}{llll}
\hline \multirow{2}{*}{ Komponen } & \multicolumn{3}{c}{ Konsentrasi edible coating dari sarang lebah } \\
\cline { 2 - 4 } & \multicolumn{2}{c}{$6 \%$} & \multicolumn{2}{c}{$9 \%$} & $12 \%$ \\
\hline Edible coating sarang lebah & 60 gram & 90 gram & 120 gram \\
\hline TEA & 40 gram & 40 gram & 40 gram \\
\hline Asam Oleat & 20 gram & 20 gram & 20 gram \\
\hline Aquades & 880 gram & 850 gram & 820 gram \\
\hline
\end{tabular}




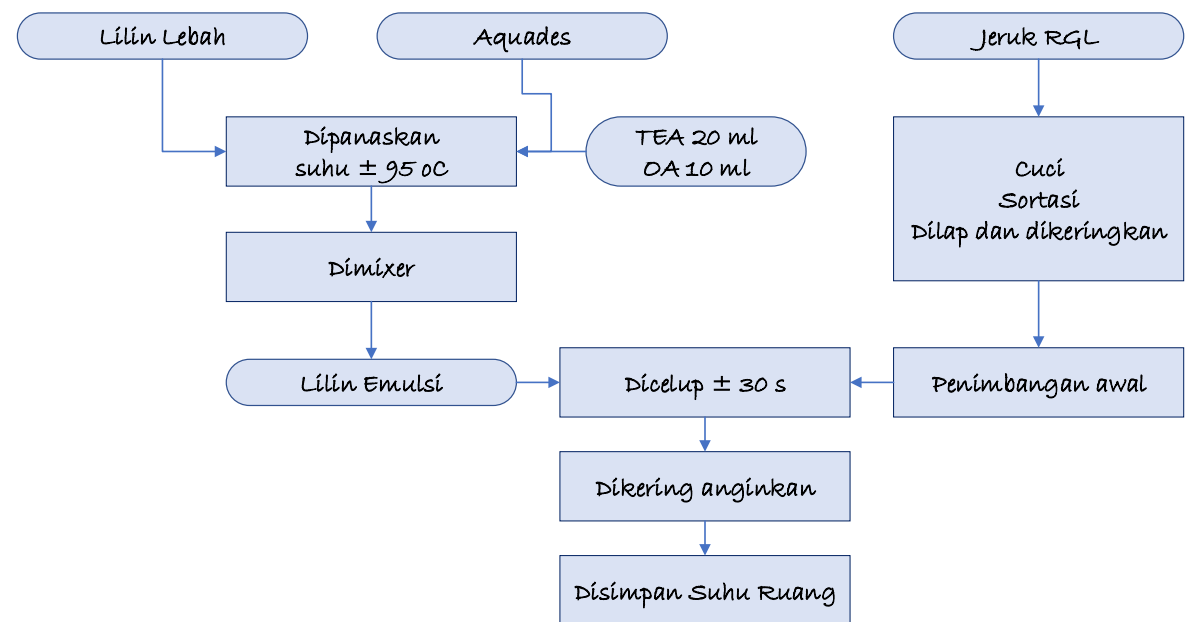

Gambar 1. Diagram Proses Pascapanen Jeruk RGL

\section{Metode Pelaksanaan dan Analsis}

Rancangan penelitian ini menggunakan metode Rancangan Acak Lengkap Faktorial yang terdiri dari dua faktor perlakuan yaitu faktor kosentrasi edible coating dari sarang lebah $\mathrm{L} 1=6 \%$, $\mathrm{L} 2=9 \%$ dan $\mathrm{L} 3=12 \%$ serta $\mathrm{L} 0=0 \%$ sebagai kontrol dan faktor kedua umur simpan $\mathrm{T} 1=0$ hari, $\mathrm{T} 2=3$ hari, $\mathrm{T} 3=6$ hari, $\mathrm{T} 4=9$ hari, $\mathrm{T} 5=12$ hari, $\mathrm{T} 6=15$ hari, T7 = 18 hari, T8 = 21 hari, T9 = 24 hari, $\mathrm{T} 10=27$ hari dan $\mathrm{T} 11=30$ hari dengan jumlah sampel yang diukur sebanyak 30 buah jeruk sebagai ulangan sehingga jeruk yang digunakan berjumlah 120 butir buah.

Selama penyimpanan jeruk RGL dilakukan pengamatan setiap tiga hari sekali. Parameter mutu yang diamati antara lain adalah susut bobot, tekstur/kekerasan kulit jeruk dan total padatan terlarut (TPT). Susut bobot jeruk RGL ditentukan dari selisih berat awal dengan berat buah setelah disimpan setiap 3 hari kemudian dibagi dengan berat awal buah, dihiting dalam persen. Tekstur atau tingkat kekerasan kulit buah jeruk diukur dengan fruit penetrometer dan kadar TPT diukur dengan alat Refraktometer.

\section{Tabel 2. Rancangan Penelitian}

\begin{tabular}{|c|c|c|c|c|c|c|c|c|c|c|c|}
\hline \multirow{2}{*}{$\begin{array}{c}\text { Kosentrasi } \\
\text { edible coating }\end{array}$} & \multicolumn{11}{|c|}{ Lama Penyimpanan (hari) } \\
\hline & 0 & 3 & 6 & 9 & 12 & 15 & 18 & 21 & 24 & 27 & 30 \\
\hline $0 \%$ & L0T0 & L0T1 & L0T2 & L0T3 & L0T4 & L0T5 & L0T6 & L0T7 & L0T8 & L0T9 & L0T10 \\
\hline $6 \%$ & L1T0 & L1T1 & L1T2 & L1T3 & L1T4 & L1T5 & L1T6 & L1T7 & L1T8 & L1T9 & L1T10 \\
\hline $9 \%$ & L2T0 & L2T1 & $\mathrm{L} 2 \mathrm{~T} 2$ & L2T3 & L2T4 & L2T5 & L2T6 & L2T7 & L2T8 & L2T9 & L2T10 \\
\hline $12 \%$ & L3T0 & L3T1 & L3T2 & L3T3 & L3T4 & L3T5 & L3T6 & L3T7 & L3T8 & L3T9 & L3T10 \\
\hline
\end{tabular}


Rumus untuk mendapatkan persen perubahan bobot adalah seperti pada persaman berikut.

$$
\begin{aligned}
\mathrm{PB}=\frac{B a-B b}{B a} \times 100 \% \\
\text { Keterangan: } \mathrm{PB}=\text { Persen perubahan bobot }(\%) \\
\mathrm{Ba}=\text { Bobot awal }(\mathrm{g}) \\
\mathrm{Bb}=\text { Bobot perlakuan hari ke- }(\mathrm{g})
\end{aligned}
$$

Sementara data hasil pengukuran tekstur buah dengan alat fruit penetrometer masih dalam bentuk satuan gaya, sehingga untuk mengetahui tekanan yang diberikan pada jeruk RGL selama penyimpanan, maka data tersebut harus dikonversi menjadi satuan tekanan dengan membaginya menggunakan satuan luas penampang yang digunakan pada fruit penetrometer. Penetro yang digunakan pada pengujian adalah dengan penampang berbentuk kerucut, oleh karena itu konversi satuan tekanan dapat dilakuakan dengan menggunakan rumus sebagai berikut:

$$
\begin{array}{ll}
\mathrm{P}=\frac{\mathrm{F}}{\mathrm{A}} \quad \mathrm{A}=\left(\pi \mathrm{r}^{2}\right) & +(\pi \mathrm{rs}) \\
\text { Keterangan }: & \mathrm{P}=\text { Tekanan }\left(\mathrm{Kgf} / \mathrm{cm}^{2}\right) \\
& \mathrm{F}=\text { Gaya }(\mathrm{Kgf}) \\
& \mathrm{A}=\text { Luas Penanpang }\left(\mathrm{cm}^{2}\right) \\
& \mathrm{r}=\text { jari-jari kerucut }(\mathrm{cm}) \\
& \mathrm{s}=\text { tinggi kerucut }(\mathrm{cm})
\end{array}
$$

Data yang diperoleh kemudian dianalisis menggunakan analisis sidik ragam, bila terdapat perbedaan yang nyata, analisis dilanjutkan dengan pengujian beda rataan perlakuan.

\section{HASIL DAN PEMBAHASAN}

Edible coating dari sarang lebah atau biasa dikenal juga dengan edible coating malam merupakan produk yang dihasilkan dari sarang dari sarang lebah. Umumnya edible coating dari sarang lebah ini tersusun oleh ester asam lemak dan berbagai senyawa alkohol rantai panjang. Dalam pengaplikasiannya, edible coating dari sarang lebah digunakan sebagai bahan tambahan makanan, bahan kosmetik, farmasi, dan sebagai pelindung kulit luar untuk buah buahan. Karena karakteristiknya yang merupakan asam lemak, edible coating dari sarang lebah tidak dapat larut dalam air begitu saja. Dibutuhkan emulsifier yang sesuai untuk membantunya larut sehingga dapat digunakan sebagai lapisan pelindung kulit jeruk RGL. Emulsifier yang digunakan untuk membantu edible coating dari sarang lebah larut dalam air adalah trietanolamim (TEA) dan asam oleat. TEA dan asam oleat merupakan campuran yang aman dan dapat menghasilkan emulsi edible coating yang stabil dan lebih homogen.

\section{Susut Bobot Selama Penyimpanan}

Hasil pengamatan terhadap susut bobot buah jeruk RGL yang sudah diberikan lapisan edible coating selama di simpan, dilakukan pengamatan setiap tiga hari sekali selama satu bulan dengan cara 
ditimbang. Sampel yang diukur sudah diberikan lapisan edible coating dengan perbedaan perlakuan berupa konsentrasi edible coating $0 \%, 6 \%, 9 \%$ dan $12 \%$. Hasil yang didapatkan menunjukan terjadinya penurunan bobot jeruk RGL selama penyimpanan.

Dari tabel 3, dapat dilihat persen perubahan bobot terbesar selama 30 hari masa penyimpanan jeruk RGL adalah dengan kadar $0 \%$ atau tidak menggunakan lapisan edible coating (Kontrol). Kehilangan bobot pada jeruk RGL yang tidak diberikan lapisan edible coating pada hari terakhir yaitu hari ke 30 sebesar $23,18 \%$. Besarnya kehilangan tersebut dapat diakumulasikan cukup besar karena bobot yang hilang bisa lebih dari seperempat dari bobot awal jeruk RGL di hari ke 0. Sedangkan persen perubahan bobot terkecil ada pada jeruk RGL yang diberikan lapisan edible coating dengan kadar $12 \%$ yaitu sebesar $8,30 \%$ bobot yang hilang.

Hasil analisis general linear model multivariate menggunakan SPSS 23, kosentrasi edible coating berpengaruh nyata terhadap susut bobot buah jeruk RGL. Susut bobot buah jeruk RGL tanpa edible coating $(0 \%)$ berbeda sangat nyata dengan edible coating $12 \%$ seperti pada tabel 4 .

Tabel 3. Persen Susut Bobot Jeruk RGL selama Penyimpanan

\begin{tabular}{|c|c|c|c|c|c|c|c|c|c|c|}
\hline \multirow{2}{*}{$\begin{array}{c}\text { Kadar } \\
\text { edible } \\
\text { coating }\end{array}$} & \multicolumn{10}{|c|}{ Penurunan bobot jeruk RGL selama 30 hari masa penyimpanan (\%) } \\
\hline & 3 & 6 & 9 & 12 & 15 & 18 & 21 & 24 & 27 & 30 \\
\hline $0 \%$ & 4,57 & 7,81 & 9,51 & 11,41 & 13,51 & 15,60 & 17,67 & 20,16 & 21,85 & 23,18 \\
\hline $6 \%$ & 3,48 & 3,84 & 6,30 & 5,49 & 6,40 & 6,76 & 7,50 & 7,67 & 9,31 & 10,22 \\
\hline $9 \%$ & 4,73 & 6,83 & 8,09 & 8,78 & 9,49 & 10,37 & 11,25 & 11,78 & 12,66 & 13,53 \\
\hline $12 \%$ & 2,71 & 3,67 & 4,45 & 4,82 & 5,22 & 5,79 & 6,38 & 7,15 & 7,53 & 8,30 \\
\hline
\end{tabular}

Tabel 4. Hasil Uji Lanjut Analisis General Linear Model Multivariate Menggunakan SPSS 23 Pengaruh Kosentrasi Edible Coating terhadap Susut Bobot Jeruk Duncan ${ }^{a, b}$ RGL selama Penyimpanan

\begin{tabular}{cccccc}
\hline Kosentrasi & $\mathrm{N}$ & \multicolumn{4}{c}{ Subset } \\
\cline { 4 - 6 } & 30 & 5.6013 & 2 & 3 & 4 \\
$6 \%$ & 30 & & 6.6970 & & \\
$9 \%$ & 30 & & & 9.7513 & \\
$0 \%$ & 30 & & & & 14.5263 \\
\hline Sig. & & 1.000 & 1.000 & 1.000 & 1.000 \\
\hline
\end{tabular}

Means for groups in homogeneous subsets are displayed. Based on observed means.

The error term is Mean Square (Error) $=.755$.

a. Uses Harmonic Mean Sample Size $=30.000$.

b. Alpha $=, 05$ 
Lama waktu penyimpanan juga berpengaruh nyata terhadap penurunan susut buah jeruk RGL. Semakin lama buah jeruk disimpan maka berat jeruk semakin berkurang. Hal ini dapat dilihat pada tabel 5 .

Perubahan bobot yang terjadi pada jeruk RGL selama penyimpanan dikarenakan jeruk RGL masih mengalami proses metabolisme, sehingga terjadi penguapan air dari proses respirasi. Penguapan air dapat disebabkan oleh tingginya suhu penyimpanan sehingga yang menyebabkan tingkat laju transpirasi dan laju respirasi masih terjadi pada jeruk RGL selama penyimpanan. Rata-rata suhu dan kelembaban dari tempat penyimpanan jeruk RGL selama penyimpanan adalah $\begin{array}{llllll}\text { sebesar } 27 & { }^{0} \mathrm{C} & \text { dengan } & \mathrm{RH} & 72 \%\end{array}$ Kehilangan air inilah yang menyebabkan bobot dari jeruk RGL selama disimpan menjadi menurun. Kehilangan air selama penyimpanan jeruk RGL tidak hanya mengurangi bobotnya saja, tetapi juga menurunkan mutu dan menimbulkan kerusakan selama penyimpanan.

Tabel 5. Hasil Uji Lanjut Analisis General Linear Model Multivariate menggunakan Duncan ${ }^{\mathrm{a}, \mathrm{b}}$ SPSS 23 Pengaruh Lama Penyimpanan terhadap Susut Bobot Jeruk RGL

\begin{tabular}{|c|c|c|c|c|c|c|c|c|c|c|}
\hline \multirow[b]{2}{*}{ Waktu } & \multirow[b]{2}{*}{$\mathrm{N}$} & \multicolumn{9}{|c|}{ Subset } \\
\hline & & 1 & 2 & 3 & 4 & 5 & 6 & 7 & 8 & 9 \\
\hline 3 hari & 12 & 3.8742 & & & & & & & & \\
\hline 6 hari & 12 & & 5.5392 & & & & & & & \\
\hline 9 hari & 12 & & & 7.0833 & & & & & & \\
\hline 12 hari & 12 & & & 7.6267 & & & & & & \\
\hline 15 hari & 12 & & & & 8.6542 & & & & & \\
\hline 18 hari & 12 & & & & & 9.6317 & & & & \\
\hline 21 hari & 12 & & & & & & 0.6992 & & & \\
\hline 24 hari & 12 & & & & & & & 1.6892 & & \\
\hline 27 hari & 12 & & & & & & & & 2.8358 & \\
\hline 30 hari & 12 & & & & & & & & & 13.8067 \\
\hline Sig. & & 1.000 & 1.000 & .130 & 1.000 & 1.000 & 1.000 & 1.000 & 1.000 & 1.000 \\
\hline
\end{tabular}

Means for groups in homogeneous subsets are displayed. Based on observed means.

The error term is Mean Square(Error) $=.755$

a. Uses Harmonic Mean Sample Size $=12.000$

b. Alpha $=, 05$. 


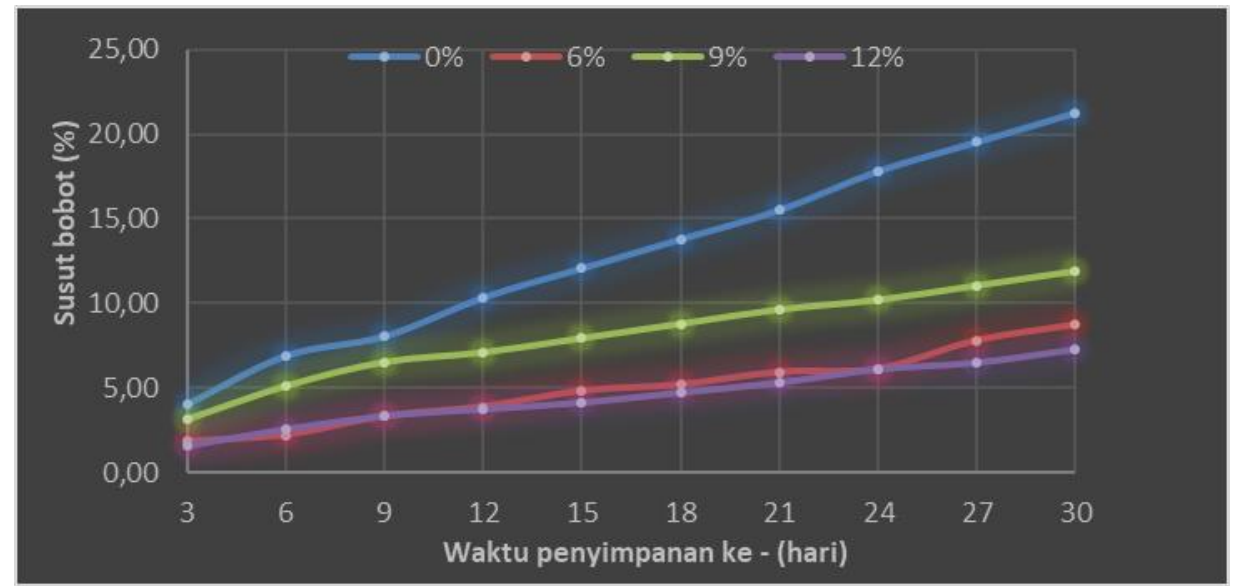

Gambar 2. Grafik persen penurunan bobot jeruk RGL selama penyimpanan

Buah jeruk RGL yang disimpan mengalami penurunan bobot ketika dilakukan pengamatan selama 30 hari. Dari gambar 2 terlihat setiap perlakuan yang diberikan edible coating dengan kadar berbeda-beda juga mengalami perubahan bobot. Dari perhitungan persen susut bobot membuktikan bahwa lapisan edible coating dengan kadar $12 \%$ dapat menekan laju respirasi sehingga mengurangi air yang menguap selama penyimpanan jeruk RGL. Sama hal nya dengan hasil penelitian yang dilakukan oleh Dhyan (2014) ketika buah jambu disimpan pada suhu ruang $\left(27^{\circ} \mathrm{C}\right)$ dan tanpa pelapisan lilin lebah hanya dapat bertahan 3 hari. Sedangkan pada suhu ruang $\left(27^{\circ} \mathrm{C}\right)$ dengan diberi lapisan lilin lebah dapat bertahan hingga 9 hari serta pada suhu rendah $\left(5{ }^{\circ} \mathrm{C}\right.$ dan $\left.10{ }^{\circ} \mathrm{C}\right)$ dengan diberi pelapisan lilin lebah dapat bertahan hingga 15 hari (Dhyan, 2014). Hal ini sesuai dengan hasil penelitian yang dilakukan oleh Dewayani W dkk., 2018 yang meyatakan bahwa kemasan dos karton yang disekat dan diedible coating dengan susut bobot terkecil (1,76 $1,95 \%)$, lebar buah normal (14,5 - 19,3 $\mathrm{cm})$, kandungan vitamin $\mathrm{C}$ paling tinggi $(24,02$ - 34,36\%), kadar asam $(65,00$ $68,74 \%)$ dan kadar gula tinggi $(8,85-$ 11,79 Brix).

\section{Tekstur/Kekerasan Kulit Jeruk}

Parameter lain yang diamati selama penyimpanan jeruk RGL adalah tekstur/kekerasan kulit jeruk. Pengujian tekstur/kekerasan kulit jeruk RGL atau bisa disebut juga dengan tingkat kekerasannya, dilakukan dengan menggunakan alat uji fruit penetrometer. Ujung penetro untuk pengujian komoditas jeruk adalah dengan menggunakan penetro berbentuk kerucut. Satuan yang terbaca ketika pengujian tingkat kekerasan menggunakan fruit penetrometer adalah 
$\mathrm{Kg}$ force. Kapasitas pengujian fruit penetrometer maksimal hanya sampai 1 Kg force. Semakin mendekati angka satu, maka tekstur kulit jeruk RGL yang diujikan akan semakin keras, begitu pula sebaliknya.

Prinsip kerja fruit penetrometer sebenarnya melihat berapa gaya tahan dari buah tersebut jika dikenakan gaya yang diberikan ketika pengukuran. Gaya yang ditahan tersebut akan dibagi dengan luas penampang penetro yang langsung bersentuhan dengan bahan yang diuji sehingga mendapatkan informasi tekanan dari tekstur buah yang sudah dilakukan pengukuran. Peedible coatingan yang dilakukan pada jeruk RGL diharapkan mampu menahan kualitas jeruk RGL selama disimpan dan mempertahankan tekstur kekerasan jeruk RGL tersebut.

Tekstur kekerasan kulit jeruk RGL selama penyimpanan merupakan salah satu faktor yang dapat dilihat untuk mengukur mutu dan kualitas jeruk RGL selama penyimpanan. Tekstur yang keras menandakan jeruk RGL memiliku kualitas yang baik, sedangkan tekstur yang lembut menandakan kualitas jeruk RGL menurun selama penyimpanan. Kebusukan dapat terjadi selama penyimpanan jeruk RGL, jeruk RGL yang mengalami pembusukan selama penyimpanan cenderung memiliki tekstur kulit buah yang lembut dan berbau tidak sedap. Kulit buah yang lebab juga menandakan kerusakan terjadi pada jeruk RGL selama penyimpanan, dan kulit jeruk yang lembab cenderung memiliki tekstur yang lembut.

Pengukuran tekstur/kekerasan kulit jeruk RGL dilakukan setiap tiga hari sekali selama 30 hari masa penyimpanan dengan pengambilan tiga sampel jeruk RGL setiap pengamatan sebagai ulangan. Hal ini dilakukan karena untuk sekali pengamatan dapat meyebabkan kerusakan jeruk ketika pengujian dilakukan. Pengamatan setiap harinya digunakan jeruk yang berbeda-beda dengan ketiga perlakuan pemberian edible coating tersebut. Penetrometer yang digunakan memiliki bentuk penampang kerucut dengan diameter sebesar $12 \mathrm{~mm}$ dan tinggi $10 \mathrm{~mm}$ sehingga luas penampangnya setelah dihitung sebesar $3,0144 \mathrm{~cm}^{2}$, digunakan rumus seperti persamaan diatas maka data gaya yang telah didapatkan, bisa dikonversi menjadi satuan tekanan seperti pada tabel 6 .

Pemberian edible coating dipercaya dapat menekan laju kerusakan jeruk RGL selama disimpan. Edible coating dari sarang lebah yang melindungi jeruk RGL dapat mempertahankan tingkat kekerasan jeruk RGL sehingga mempertahankan mutu dan kualitasnya di mata konsumen. Hasil pengujian dapat dilihat pada hari terakhir penyimpanan, jeruk RGL yang tidak dilindungi oleh 
edible coating dari sarang lebah cenderung memiliki tekstur yang lebih lembut dan terlihat ketika penyimpanan di hari ke-30 pada data di tabel 5 sebesar $0,27 \mathrm{Kgf} / \mathrm{cm}^{2}$. Walaupun memiliki tektur paling kecil dibandingan dengan jeruk RGL yang dilapisi oleh lapisan edible coating, angka tersebut cukup besar dan masih merupakan skala yang dapat diterima di pasaran untuk tingkat kekerasan jeruk RGL selama disimpan.

Gambar 3 memperlihatkan tingkat kekerasan jeruk RGL selama penyimpanan dalam waktu 30 hari. Tekstur jeruk yang paling lembut terdapat pada jeruk RGL yang tidak diberikan lapisan edible coating atau dengan kadar $0 \%$ pada hari ke 9. Sedangkan tekstur jeruk RGL yang paling keras terdapat pada jeruk yang diberikan lapisan edible coating dengan kadar $12 \%$ pada hari penyimpanan ke 3. Keanekaragaman data yang didapatkan terjadi karena pengujian yang dilakukan setiap 3 hari pengamatan ini menggunakan jeruk RGL yang berbeda-beda setiap harinya. Hal ini dikarenakan buahn yang telah digunakan dalam pengujian tidak dapat digunakan lagi pada pengujian hari berikutnya karena buah tersebut telah rusak.

Tabel 6. Konversi Pengukuran Tekanan menggunakan Fruit Penetrometer

\begin{tabular}{ccccccccccc}
\hline $\begin{array}{c}\text { Kadar } \\
\text { edible } \\
\text { coating }\end{array}$ & $\mathbf{3}$ & $\mathbf{6}$ & $\mathbf{9}$ & $\mathbf{1 2}$ & $\mathbf{1 5}$ & $\mathbf{1 8}$ & $\mathbf{2 1}$ & $\mathbf{2 4}$ & $\mathbf{2 7}$ & $\mathbf{3 0}$ \\
\cline { 2 - 11 }$y$ & 0,30 & 0,30 & 0,24 & 0,29 & 0,26 & 0,28 & 0,27 & 0,26 & 0,28 & 0,27 \\
\hline $\mathbf{0 \%}$ & 0,31 & 0,31 & 0,30 & 0,31 & 0,31 & 0,29 & 0,30 & 0,27 & 0,30 & 0,31 \\
\hline $\mathbf{6 \%}$ & 0,30 & 0,31 & 0,26 & 0,28 & 0,29 & 0,25 & 0,28 & 0,27 & 0,26 & 0,30 \\
\hline $\mathbf{9 \%}$ & 0,32 & 0,31 & 0,28 & 0,27 & 0,30 & 0,30 & 0,30 & 0,28 & 0,31 & 0,31 \\
\hline $\mathbf{1 2 \%}$ & & & & & & & & & \\
\hline
\end{tabular}

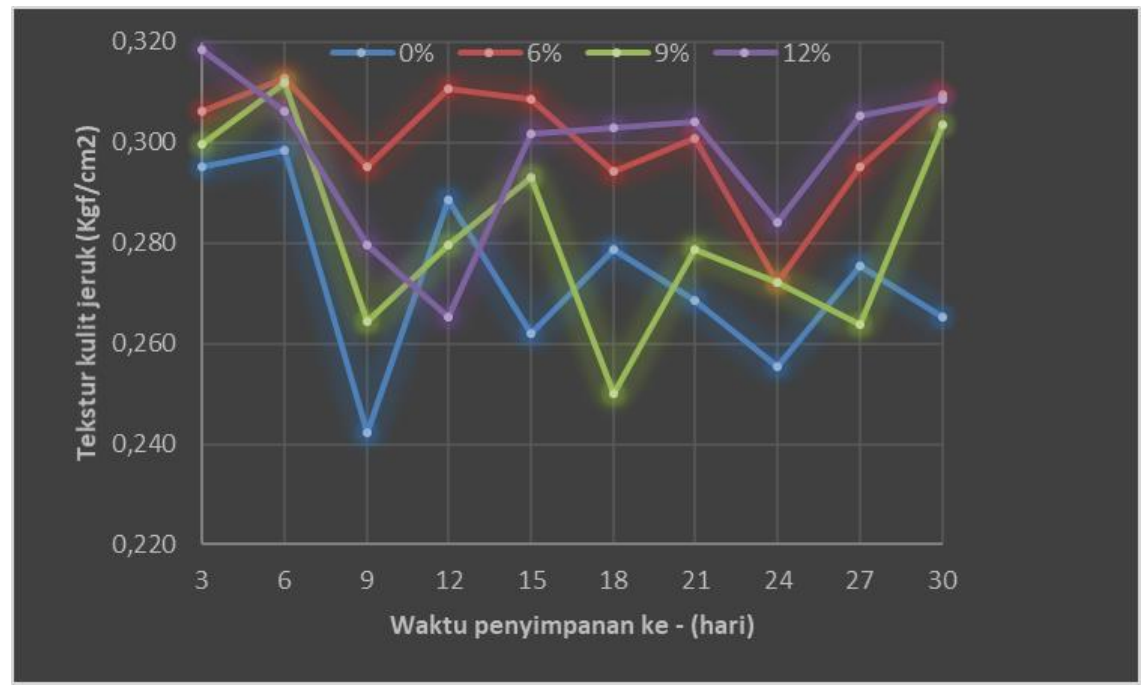

Gambar 3. Grafik Tingkat Kekerasan Jeruk RGL selama Penyimpanan 
Hasil analisis general linear model multivariate menggunakan SPSS 23, pengaruk kosentrasi edible coating terhadap tektur kulit buah jeruk RGL selama penyimpanan dapat dilihat pada tabel 7. Sementara hasil analisis pengaruh lama waktu penyimpanan terhadap tekstur kulit buah jeruk dapat dilihat pada tabel 8 . Hasil analisis menunjukkan bahwa pemberian lapisan edible coating dapat mempertahankan tekstur/tingkat kekerasan kulit buah jeruk RGL selama 30 hari penyimpanan.

Tabel 7. Hasil Uji Lanjut Analisis General Linear Model Multivariate menggunakan SPSS 23 Pengaruh Kosentrasi Edible Coating terhadap Tekstur Kulit Buah Jeruk RGL selama Penyimpanan

Duncan ${ }^{\mathrm{a}, \mathrm{b}}$

\begin{tabular}{lllllr}
\hline \multirow{2}{*}{ Kosentrasi } & $\mathrm{N}$ & \multicolumn{5}{c}{ Subset } \\
\cline { 3 - 6 } $0 \%$ & 30 & 27.2000 & 2 & 3 & 4 \\
\hline $9 \%$ & 30 & & 28.1000 & \\
\hline $12 \%$ & 30 & & & 29.5000 & 30.0333 \\
\hline $6 \%$ & 30 & 1.000 & 1.000 & 1.000 & 1.000 \\
\hline Sig. & & & & & \\
\hline
\end{tabular}

Means for groups in homogeneous subsets are displayed. Based on observed means.

The error term is Mean Square(Error) $=.883$.

a. Uses Harmonic Mean Sample Size $=30.000$.

b. Alpha $=, 05$.

Tabel 8. Hasil Uji Lanjut Analisis General Linear Model Multivariate menggunakan SPSS 23 Pengaruh Lama Penyimpanan terhadap Tekstur Jeruk RGL

Duncan $^{\mathrm{a}, \mathrm{b}}$

\begin{tabular}{|c|c|c|c|c|c|}
\hline \multirow[b]{2}{*}{ Waktu } & \multirow[b]{2}{*}{$\mathrm{N}$} & \multicolumn{4}{|c|}{ Subset } \\
\hline & & 1 & 2 & 3 & 4 \\
\hline 6 hari & 12 & 27.0000 & & & \\
\hline 21 hari & 12 & 27.0000 & & & \\
\hline 15 hari & 12 & & 28.0000 & & \\
\hline 9 hari & 12 & & 28.7500 & 28.7500 & \\
\hline 24 hari & 12 & & 28.7500 & 28.7500 & \\
\hline 12 hari & 12 & & & 29.0000 & \\
\hline 18 hari & 12 & & & 29.0000 & \\
\hline 27 hari & 12 & & & 29.5000 & \\
\hline 30 hari & 12 & & & 29.5833 & \\
\hline 3 hari & 12 & & & & 30.5000 \\
\hline Sig. & & 1.000 & .067 & .059 & 1.000 \\
\hline
\end{tabular}

Means for groups in homogeneous subsets are displayed. Based on observed means.

The error term is Mean Square(Error) $=.883$.

a. Uses Harmonic Mean Sample Size $=12.000$.

b. Alpha $=, 05$. 


\section{Total Padatan Terlarut}

Gula merupakan komponen utama dalam zat padat terlarut, sehingga untuk menentukan kadar gula dalam suatu cairan dapat dilakukan dengan mengukur besarnya kadar total padatan terlarutnya. Alat yang dapat digunakan untuk mengukur Total Padatan Terlarut (TPT) dalam buah-buahan adalah Refraktometer. Satuan yang terbaca dalam pengukuran TPT adalah derjad Brix dalam persen (\%). Semakin besar nilai derajad Brixnya maka akan semakin manis buah yang diamati, begitu pula sebaliknya.

Nilai TPT diukur menggunakan refraktometer dengan cara meneteskan sari buah jeruk RGL keatas kaca pengamat refraktometer. Karena untuk pengamatan ini diambil sari buahnya, jeruk RGL yang sudah diamati tidak dapat diukur kembali pada pengamatan hari berikutnya karena sudah rusak secara fisik. Rata rata hasil pengukuran pada beberapa kosentrasi pelapisan edible coating dari sarang lebah terhadap total padatan terlarut jeruk RGL selama penyimpanan 30 hari disajikan dalam tabel 9.

Pada dasarnya, total padatan terlarut pada buah-buahan akan cenderung meningkat pada awal masa penyimpanan dan akan menurun pada akhir masa simpan. Begitu pula yang terjadi pada penyimpanan jeruk RGL. Penggunaan edible coating pada penyimpanan jeruk RGL tidak mempengaruhi tingkat kemanisan dari jeruk RGL yang disimpan, akan tetapi lamanya penyimpanan jeruk akan membuat kadar gula dalam jeruk RGL mengalami perubahan alkohol, aldehida, dan asam amino.

Tabel 9. Data Pengukuran Total Padatan Terlarut pada Jeruk RGL menggunakan Refraktometer selama Penyimpanan

\begin{tabular}{cccccccccccc}
\hline $\begin{array}{c}\text { Kadar edible } \\
\text { coating }\end{array}$ & \multicolumn{8}{c}{ Total padatan terlarut pada Penyimpanan hari ke - $(\%$ Brix $)$} \\
\cline { 2 - 12 } & $\mathbf{0}$ & $\mathbf{3}$ & $\mathbf{6}$ & $\mathbf{9}$ & $\mathbf{1 2}$ & $\mathbf{1 5}$ & $\mathbf{1 8}$ & $\mathbf{2 1}$ & $\mathbf{2 4}$ & $\mathbf{2 7}$ & $\mathbf{3 0}$ \\
\hline $\mathbf{0 \%}$ & 8,50 & 12,37 & 10,57 & 11,63 & 11,57 & 10,73 & 10,67 & 9,57 & 9,30 & 11,50 & 11,50 \\
\hline $\mathbf{6 \%}$ & 10,47 & 10,17 & 9,57 & 9,87 & 10,40 & 10,80 & 9,30 & 10,60 & 10,03 & 9,60 & 9,73 \\
\hline $\mathbf{9 \%}$ & 9,63 & 10,67 & 10,57 & 9,63 & 10,63 & 9,30 & 10,60 & 9,27 & 9,83 & 10,20 & 11,03 \\
\hline $\mathbf{1 2 \%}$ & 10,70 & 10,17 & 10,67 & 9,40 & 10,93 & 11,37 & 10,23 & 9,90 & 10,60 & 8,90 & 9,77 \\
\hline
\end{tabular}




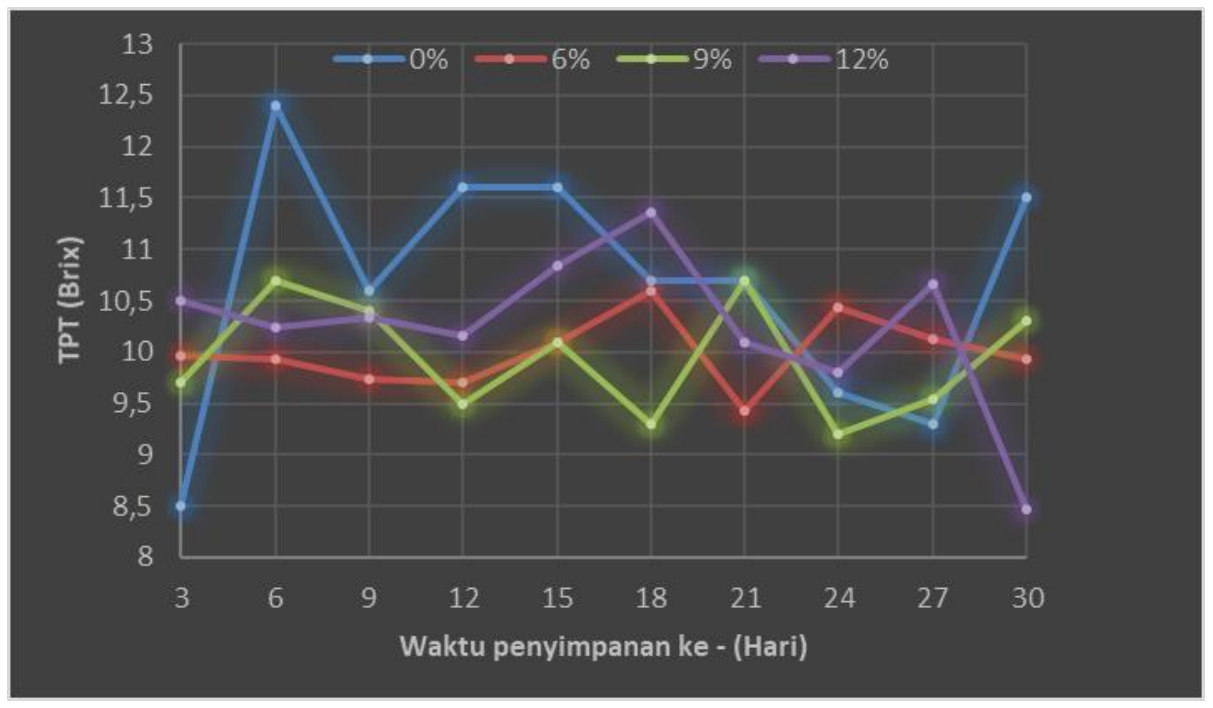

Gambar 4. Grafik TPT pada Jeruk RGL selama 30 Hari Masa Penyimpanan

Hasil analisis general linear model multivariate menggunakan SPSS 23, pengaruh kosentrasi edible coating terhadap total padatan terlarut buah jeruk RGL selama penyimpanan dapat dilihat pada tabel 10 .

Dari hasil analaisis pada tabel 10 terlihat bahwa pelapisan edible coating berbeda nyata dengan tanpa edible coating. Sementara kosentrasi edible coting tidak berpengaruh nyata. Padatan terlarut buah jeruk semakin menurun dengan semakin tingginya konsentrasi edible coating dari sarang lebah sampai konsentrasi $6 \%$ kemudian meningkat lagi pada konsentrasi 9\%. Pelapisan edible coating dapat mengurangi laju respirasi sedangkan konsentrasi yang terlalu tinggi dapat mengakibatkan timbulnya respirasi anaerob di dalam buah sehingga padatan terlarut meningkat (Pantastico, 1986). Menurut Walker (1983), konsentrasi edible coating yang terlalu tinggi dapat memacu proses degradasi makromolekul menjadi molekul-molekul terlarut sehingga padatan terlarut semakin besar. Selain itu dapat disebabkan juga oleh tidak meratanya TPT pada setiap buah dan bahkan dalam satu buah jeruk RGL yang disimpan selama 30 hari penyimpanan. Ketidak seragaman dan tidak teraturnya kenaikan atau penurunan kadar gula dalam jeruk RGL juga dipengaruhi oleh perubahan gula-gula sederhana ketika masa penyimpanan jeruk RGL. 
Tabel 10. Hasil Uji Lanjut Analisis General Linear Model Multivariate menggunakan SPSS 23 Pengaruh Kosentrasi Edible Coating terhadap TPT Buah Jeruk RGL selama Penyimpanan

Duncan ${ }^{a, b}$

\begin{tabular}{lccc}
\hline & & \multicolumn{2}{c}{ Subset } \\
\cline { 3 - 4 } Kosentrasi & $\mathrm{N}$ & 1 & 2 \\
\hline $6 \%$ & 30 & 10.0067 & \\
\hline $9 \%$ & 30 & 10.1733 & \\
\hline $12 \%$ & 30 & 10.1933 & 10.9400 \\
\hline $0 \%$ & 30 & & 1.000 \\
\hline Sig. & & .495 &
\end{tabular}

Means for groups in homogeneous subsets are displayed. Based on observed means.

The error term is Mean Square(Error) $=.976$.

a. Uses Harmonic Mean Sample Size $=30.000$.

b. Alpha $=, 05$.

Tabel 11. Hasil Uji Lanjut Analisis General Linear Model Multivariate menggunakan SPSS 23 Pengaruh Lama Penyimpanan terhadap Total Padatan Terlarut Jeruk RGL

Duncan ${ }^{\mathrm{a}, \mathrm{b}}$

\begin{tabular}{|c|c|c|c|c|}
\hline \multirow[b]{2}{*}{ Waktu } & \multirow[b]{2}{*}{$\mathrm{N}$} & \multicolumn{3}{|c|}{ Subset } \\
\hline & & 1 & 2 & 3 \\
\hline 21 hari & 12 & 9.8333 & & \\
\hline 24 hari & 12 & 9.9417 & 9.9417 & \\
\hline 27 hari & 12 & 10.0500 & 10.0500 & 10.0500 \\
\hline 9 hari & 12 & 10.1333 & 10.1333 & 10.1333 \\
\hline 18 hari & 12 & 10.2000 & 10.2000 & 10.2000 \\
\hline 6 hari & 12 & 10.3417 & 10.3417 & 10.3417 \\
\hline 30 hari & 12 & 10.5083 & 10.5083 & 10.5083 \\
\hline 15 hari & 12 & 10.5500 & 10.5500 & 10.5500 \\
\hline 3 hari & 12 & & 10.8417 & 10.8417 \\
\hline 12 hari & 12 & & & 10.8833 \\
\hline Sig. & & .135 & .059 & .081 \\
\hline
\end{tabular}

Means for groups in homogeneous subsets are displayed. Based on observed means.

The error term is Mean Square(Error) $=.976$.

a. Uses Harmonic Mean Sample Size $=12.000$

b. Alpha $=, 05$.

Total padatan terlarut (TPT) adalah faktor selanjutnya yang dilihat dari jeruk RGL selama disimpan. Pengukuran TPT dilakukan juga setiap tiga hari sekali dalam penyimpanan jeruk RGL selama sebulan. TPT diukur dengan menggunakan refraktometer sehingga diketahui berapa padatan terlarut yang terkandung dalam jeruk RGL selama disimpan. Informasi yang didapatkan dari refraktometer menggunakan satuan derajad Brix yang biasanya digunakan untuk mengetahui tingkat kemanisan buah-buahan. Semakin besar nilai derajat Brix yang terbaca pada refraktometer, maka semakin manis juga buah tersebut. Edible coating yang dilakukan terhadap jeruk RGL selama penyimpanan 
diharapkan mampu menahan kualitas tingkat kemanisan buah jeruk RGL tersebut.

\section{KESIMPULAN}

1. Pada peyimpanan jeruk RGL, penggunaan edible coating sebagai lapisan pelindung di bagian luar kulit jeruk diketahui mampu menahan kerusakan dan mempertahankan kualitas jeruk RGL.

2. Kadar edible coating $12 \%$ diketahui yang paling baik dalam melindungi jeruk RGL selama penyimpanan terlihat dari tekstur, TPT dan susut bobot yang dialami jeruk RGL.

3. Total padatan terlarut pada jeruk RGL yang dilakukan penyimpanan selama 30 hari diketahui tidak memiliki pengaruh cukup besar terhadap peedible coatingan jeruk RGL.

\section{UCAPAN TERIMA KASIH}

Terimakasih kami sampaikan kepada Bapak Dr. Ir. Darkam Musaddad, M.Si selaku kepala Balai Pengkajian Teknologi Pertanian Bengkulu dan Bapak Dr. Rudi Hartono, SP, MP Selaku Kasie Kerjasama dan Pelayanan Pengkajian Balai Pengkajian Teknologi Pertanian yang telah memberi saran, arahan dan petunjuk serta memfasilitasi dalam pelaksanaan penelitian ini. Teman teman terkhusus buat Muhammad Hanief
Baihaqqi Pratama dan Ibu Sulasih yang telah membantu dalam melakukan tahapan proses pengolahan dan pengumpulan data.

\section{DAFTAR PUSTAKA}

Akadongan H. 1999. High moisture food extrusion. Int J Food Sci Tech 34: 195-207. DOI: 10.1046/j. 13652621. 1999.00256.x

Badan Standardisasi Nasional. 2015. Standar Nasional Indonesia Jeruk Keprok. SNI-01-3165-1992.

Badan Pusat Statistik. 2017. Katalog Provinsi Bengkulu Dalam Angka. BPS Provinsi Bengkulu. Bengkulu.

Brown, R, H. 1981. Beeswax (2nd edition) Bee Books New and Old. UK:

Somerset.

Coggshall, William L. And Roger A. Morse. 1984. Beeswax Production, Harvesting, Processing and Products. Newyork: Wicwas Press.

Davies, F.S. dan L.G. Albrigo. 1998. Citrus. The University Press. Cambridge. 13-51 pp.

DeMan, J.M. 1997. Kimia Makanan. K. Panduwinata, penerjemah. Bandung : ITB Press. Harper, J.M. 1981. Extruction of Food. Vol II. CRC Press Inc. Florida. Page 5253.

Dewayani, W., R. Syamsuri, Nurjanani dan W. Halil. 2018. Pengaruh kemasan dan peedible coatingan terhadap mutu jeruk Pamelo Pangkep Merah setelah pengangkutan. Gorontalo Agriculture Technology Journal. 1 (2) 27-34.

Dhyan. S. Christina, dkk. 2014. Pengaruh Pelapisan Lilin Lebah dan Suhu Penyimpanan terhadap Kualitas Buah Jambu Biji (Psidium guavaja L.). Jurnal Bioproses Komoditas Tropis Vol. 2 No. 1. 
Furness, C., 1997. How to Make Beeswax Candles. British Bee Publ. Geddington, UK.

Ismiarni. 1996. Mempelajari Penggunaan Lilin Lebah (Beeswax) untuk Pembuatan "Shortening" dan Margarin Rendah Kalori. Skripsi Jurusan Teknologi Pangan dan Gizi Fakultas Teknologi Pertanian Institut Pertanian Bogor.

Kader, A.2006. Mangosteen facts, Recommendations for Maintaining Postharvest Quality. http://postharvest.ucdavis.edu.sht $\mathrm{ml}$.

Kementerian Pertanian RI. 2018. Sejuta Benih Keprok Unggul Untuk Rakyat. http://www.pertanian.go.id/home/? show $=$ news \&act $=$ view \&id $=3273$. 4 Maret 2019.

Les Crowder. 2012. Top-Bar Beekeeping: Organic Practices for Honeybee Health. Chelsea: Green Publishing.
Pantastico, Er.B., 1986. Fisiologi Pasca Panen. Gadjah Mada University Press, Yogyakarta.

Rosjonsyah, H., R. P. Warman, E. Gustanto, B. Suwantoro. 2012. Deskripsi Jeruk Varietas RGL. Dinas Pertanian dan Ketahanan Pangan Kabupaten Lebong.

Soelarso. 1996. Budidaya Jeruk Bebas Penyakit. Kanisius, Jakarta.

Suwantoro, B. 2010. Mengenal Jeruk Rimau Gerga Lebong Lebih Dekat. Balai Benih Hortikultura Rimbo Pengadang. Dinas Pertanian dan Ketahanan Pangan Kabupaten Lebong.

Sihombing, D.T.H., 1997. Ilmu Ternak Dari sarang lebah Madu. Gadjah Mada University Press, Yogyakarta.

Walker, P., 1983. Beeswax : Composition, Properties, Adulteration. IBRA, London. 